\title{
EMPIRICS OF THE TRADITIONAL U.S. PHILLIPS CURVE: EVIDENCE FROM 1930-2016
}

Muhammad Mustafa

South Carolina State University • Orangeburg, SC

Matiur Rahman

McNeese State University • Lake Charles, LA

\section{ABSTRACT}

This study revisits the trade-off relationship between inflation and unemployment rates for the USA, as observed by the traditional Philips curve. Annual data are used from 1930 to 2016. The ARDL Bounds Testing approach is applied accompanying efficient unit roots testing [(DF-GLS) and (Ng-Perron) tests] and the determination of the order of integration of the variables in levels. The ARDL Bounds testing estimates confirm co-integration between the above variables. The estimates of error-correction model (ECM) clearly support the existence of the traditional Philips curve for the long run, but subdued for the short run. However, there is evidence of short-run interactive feedback effect between the variables.

Key Words: Phillips Curve, Efficient Unit Root Testing, ARDL, Bounds Testing, VECM JEL Classifications: E24, E31, E32

\section{INTRODUCTION}

The traditional Phillips curve is an empirical observation from statistical plots of UK's wage inflation and unemployment rates over 1861-1957 revealing a tradeoff (inverse) relationship between the above (Phillips, 1958). This relationship is useful to formulation and implementation of monetary and fiscal policies striving for a comfortable combination of both to ensure macroeconomic stability. To keep inflation at a tolerable level and to reduce unemployment rate toward a full employment level is a serious challenge to macroeconomic policymakers. At the same time, the Phillips curve underscores the limitation of macroeconomic policies to deal with both problems simultaneously over various phases of near-inevitable business cycle. For example, expansionary policies are invoked during recession period to reduce unemployment rate risking future surge in inflation rate.

Conversely, contractionary policies are pursued to tame rising inflation rate risking future higher underemployment rate during a period of strong economic recovery. 
During the 1970s oil crisis, the US economy experienced stagflation questioning the existence of the Phillips curve. Again, the reversal of stagflation to soft-landing during the 1990s posed the same question. The most recent US Great Recession (December 2007-June, 2009) called for unprecedented expansionary monetary and fiscal policies. Amid fluctuations, the unemployment rate from a peak of $10 \%$ in 2009 tepidly came down to $4.2 \%$ in September, 2017 with persistent average inflation rate at $1.5 \%$ annually in recent years. This is below the Fed's hypothesized $4.6 \%$ natural unemployment rate. But inflation rate is not rising. Seemingly, this is inconsistent with the assertion of the traditional Phillips curve. Prevailing low inflation during the period is largely attributed to several global factors (e.g., plunging crude oil price, strong US dollar, falling metal prices, slowing of China's economy). Questions are also being raised regarding the short-run and long-run validity of the Phillips curve including its stability.

In light of the foregoing brief discussions, this topic merits a further empirical revisit in the US context analyzing data for 1930-2016. Thus, the sole focus of this econometric inquiry is to obtain additional insights. The autoregressive distributive lag (ARDL) Bounds testing and vector error-correction (VECM) models are implemented. The remainder of the paper proceeds as follows: brief review of the related empirical literature; empirical methodology; results and conclusions with policy implications.

\section{BRIEF REVIEW OF RELATED EMPIRICAL LITERATURE}

Phillips (1958) inspired numerous subsequent theoretical and empirical studies for validation, refutation and questioning the existence of the traditional Phillips curve (e.g., Lipsey, 1960; Solow, 1970; Onder, 2004).

Lipsey (1960) finds an inverse relation for UK prior to the World War-I (19141918), but not after the World War-II. Turner (1997) argues that structural break since the 1970s in UK's economy may have caused the instability of the traditional Phillips curve. He emphasizes more on the stability than its existence. Atkeson and Ohanian (2001) also support Turner (1997). Hansen and Pancs (2001) find inverse relation between the series for Lativa. Bhanthumnavin (2002) finds evidence of the Phillips curve for Thailand, but only in the post -1997 Asian flu. Graham and Snower (2002) demonstrate a stable Phillips curve for Chile. They argue that the trade-off in the long run is due to inter-relation between money growth and rise in nominal wages. Using Stock-Watson procedure, Furuoka (2007) finds relation between inflation and unemployment for Malaysia, which was later confirmed by Tang and 
Lean (2007). Schreiber and Wolters (2007) apply VAR co-integration approach and find a long-run relation for Germany.

Friedman (1968) argues that this relationship is only short-run phenomenon. In the long run, workers and employers take inflation into account in employment contracts that increase pay at rates near anticipated inflation. This implies that over the long run, there is no trade- off between inflation and unemployment. Niskannen (2002) points out that the Phillips curve in its original form suffers misspecification and that the positive slope of the long-run Phillips relation may be due to lack of indexed tax code. Gali et al., (2005) and Rudd and Whelan (2005) use GMM approaches but fail to find strong Phillips curve relation. Reichel (2004) applies co-integration method to the industrialized economies but find trade-off only for the USA and Japan.

Karanassou, et al.(2008) also analyze the relation between US inflation and unemployment from the perspective of 'frictional growth'. In particular, they focus on the interaction between money growth and nominal frictions and conclude that monetary policy has not only persistent, but permanent real effects, giving rise to a long-run inflation- unemployment trade-off. Karanassou, et al. (2010) employ the chain reaction theory approach for the new Phillips curve to provide a synthesis of the traditional structural macroeconometric models and the (structural) vector autoregressions. They again show that frictional growth, i.e. the interplay between lags and growth, generates an inflation- unemployment trade-off in the long run. They, therefore, suggest that a holistic framework, such as, the chain reaction theory, should be used to jointly explain the evolution of inflation and unemployment.

Malinov and Sommers (1997), and Turner and Seghezzea (1999) both employ Seemingly Unrelated Estimation method and confirm Phillips curve relation. Eliasson (2001) specifies linear Phillips curve for Sweden, Australia, and the United States and check for parametric stability. They do not find the Phillips curve for Australia and Sweden, but find one for the USA. Unlike Islam et al. (2003) revisit the US Phillips relation using 1950-1999 data, but did not find a strong relation.

Del Boca et al. (2008) find Phillips curve for Italy for 1861-1998. The paper captures the effects of structural changes and asymmetries on the estimates of the trade-off relation and finds that a trade-off exists only during low inflation and stable aggregate supply. Russell and Banerjee (2008) investigate vertical Phillips curve assuming non-stationarity in the time series data. They find positive relation between inflation and unemployment rates in the short run for the United States. Paul (2009) argues that droughts, oil shocks and liberalization policy of the early 1990s may be the reason for the absence of a Phillips curve in India. After adjusting for the shocks, 
this study finds the evidence for the Phillips curve suggesting a short-run trade-off between inflation and industrial output for India.

Focusing on regimes of inflation and unemployment and using the statistical technique of fuzzy clustering, Ormerod et al. (2003) explore for the United States, the United Kingdom and Germany between 1971 and 2009. They report that the factors which govern the inflation/unemployment trade-off are so multi-dimensional that it is hard to identify periods of short-run Phillips curves which can be assigned to particular historical periods with any degree of accuracy or predictability. They, therefore, identify for each country three distinct regimes in inflation/unemployment space and find that similarities exist across countries in both the regimes and the timings of the transitions between regimes. According to them, the inflation/ unemployment relationship or the Phillips curve experiences from time to time major shifts. The relationship inherently is unstable even in the short run. They, however, conclude that the typical rates of inflation and unemployment experienced in the regimes are substantially different.

Fitzgerald and Nicolini (2013) could not find stable US Phillips curve over the last forty years using national annual data. In contrast, they found stable regional Phillips curves for the USA over the same period with consistent negative relationship between regional inflation and unemployment. Financial friction and shocks could imply slow recoveries and persistently low inflation. Several recent papers [e.g., Blanchard (2016); and Gilchrist and Zakrajsek (2013)] have shown that financial frictions play an important role in shaping the dynamics of prices after the recent global financial crisis. Globalization has increased the role of international factors and decreased the role of domestic factors in the inflation process in industrial economies. These hypotheses originated from the concerns of some monetary policymakers of an increasing disconnect between monetary policy on one side and domestic inflation and long-term interest rates on the other. The evidence of the importance of global factors is however mixed (Ihrig et al. 2010; Bianchi and Civelli 2015). The inability of stabilization policy duet to the effective lower bound on policy rates to lower real interest rates enough to bring the economy back to long-run sustainable levels and to achieve long- run inflation goals. Policymakers have emphasized how persistently low inflation poses substantial risks if monetary policy is constrained by the zero bound, and could derail the economic recovery (e.g., Constanciao, 2014). The studies on the evolution of the relation between inflation and unemployment [e.g., Blanchard, et al (2015); Ball and Mazumder (2011); Kiley (2015)] conclude that i) low unemployment still pushes inflation up; high unemployment pushes it down. Put another way, the US Phillips curve is alive. ii) Inflation expectations, 
however, have become steadily more anchored, leading to a relation between the unemployment rate and the level of inflation rather than the change in inflation. In this sense, the relation resembles more the Phillips curve of the 1960s than the accelerationist Phillips curve of the later period. iii) the slope of the Phillips curve, i.e., the effect of the unemployment rate on inflation at given inflation expectation, has substantially declined. But the decline dates back to 1980s rather than to the recent financial crisis. There is no evidence of further decline during the crisis. iv) the standard error of the residual in the relation is large, especially in comparison to the low level of inflation.

\section{EMPIRICAL METHODOLOGY}

The basic estimating model is specified as follows:

$\mathrm{INF}_{\mathrm{t}}=\propto+\beta \mathrm{UR}_{\mathrm{t}}+\mathrm{e}_{\mathrm{t}}$

Where, $\mathrm{INF}=$ Inflation rate, $\mathrm{UR}=$ Unemployment rate, $\mathrm{e}=$ Error term that is independently and identically disturbed, and $\mathrm{t}=$ time subscript.

This study employs the unrestricted ARDL Bounds testing approach to cointegration following the methodology proposed in [Pesaran and Pesaran (1997), Peasran and Shin (1999), Pesaran, et al. (2001)]. This methodology is preferred to classical co-integration procedures (Johansen, 1988, 1991; Johansen and Juselius, 1990) as it has certain advantages over them. For example, it can be applied regardless of the time series properties of variables in the sample. Secondly, it allows for separate unbiased inferences on long-run and short-run estimates with valid t-values which are not possible under the classical co-integration procedures. Furthermore, ARDL model can accommodate a greater number of variables in comparison to Vector Autoregressive (VAR) models. Also, this approach is applicable to relatively small sample size.

To begin with, data have to be tested for unit root. This testing is necessary to avoid the possibility of spurious regression as bounds test is based on the assumption that the variables are I(0) or I(1). If data are found I (0) or I (1), the unrestricted ARDL approach to co- integration is applied. However, for any I (2) variable, the system may crash. Thus, unit root tests are desirable to avoid this possibility. The existence of a long-run relationship between or among the variables is established by testing for the significance of one-period lagged level variables in an error-correction mechanism regression. Then, the first lags of all variables in level are added to the equation to create the error-correction mechanism equation for performing additional test by computing the F-test on the significance of all the lagged variables. The 
ARDL form of equation is estimated where the optimal lag-length is selected by Akaike (1969) Information criterion (AIC). Low AIC-value indicates good fit of the model with minimum loss of information.

The ARDL representation for co-integration is specified as follows:

$\Delta \mathrm{INF}_{t}=\beta_{0}+\sum_{i=1}^{p} \beta_{i} \Delta U R_{t-i}+\sum_{i=1}^{p} \lambda_{i} \Delta I N F_{t-i}+\psi U R_{t-1}+\gamma I N F_{t-1}+\mu_{t}$

For null hypothesis $\left(\mathrm{H}_{\mathrm{o}}\right)$ of no co-integration, $\psi=\gamma=0 \ldots \ldots$.

For alternative hypothesis $\left(\mathrm{H}_{\mathrm{A}}\right)$ of co-integration, $\psi \neq \gamma \neq 0 \ldots \ldots$

This method provides lower and upper bound critical values where the lower bound critical values assume all variables are $\mathrm{I}(0)$ and the upper bound critical values assume all variables are I(1). If the calculated F statistic exceeds the upper bound critical F-value, the null hypothesis of no co-integration is rejected. If it falls below the lower bound critical F-value, the null hypothesis of no long-term relationship cannot be rejected. However, if it falls within the bond of the above critical F-values, inference would be inconclusive. On the evidence of co-integration, an errorcorrection model using the first-differences of the variables is estimated for long-run solution, and to determine the speed of adjustment toward long-run equilibrium. A general error-correction model following Engle and Granger (1987) is specified below:

$$
\Delta \mathrm{INF}_{t}=\beta_{0}+\sum_{i=1}^{p} \beta_{i} \Delta U R_{t-i}+\sum_{i=1}^{p} \lambda_{i} \Delta I N F_{t-i}+\pi E C_{t-1}+\dot{\mu}_{t}
$$

The estimated coefficient $(\hat{\pi})$ of the error-correction term $\left(E C_{t-1}\right)$ is expected to be negative and significant in terms of the associated pseudo t-value for longrun convergence and causal flows. If $\beta_{i}$ 's and $\lambda_{i}$ 's are non-zeros, lagged changes in unemployment and inflation rates lead the current change in inflation rate in the short-run. Their relative numerical magnitudes indicate relative influence of the relevant explanatory variable on the dependent variable. The sum of the coefficients of each lagged independent variable shows its net interactive feedback effect with other variables.

To restate, annual time-series data for the USA are utilized spanning over 1930 to 2016. The relevant data are obtained from the Bureau of Economic Analysis.

\section{RESULTS}

Prior to testing for cointegration, the time series properties of the variables involved are examined. To test for unit root (nonstationarity) in the variables, the modified Dickey-Fuller (DF-GLS) test and the modified Phillips-Perron (Ng-Perron) test (Elliot et al., 1996; Ng and Perron, 2001) are applied. The fairly standard KPSS (Kwiatkowski, Phillips, Schmidt and Shin, 
1992) test for no unit root (stationarity) and the ADF and PP tests are not employed for concerns of their high sensitivity to the selection of lag-lengths. It is important to examine the time series properties of variables since an application of the Ordinary least Squares (OLS) to estimate a model with nonstationary time series data results in the phenomenon of spurious regression (Granger and Newbold, 1974) invalidating the inferences through the standard t-test and joint F- test (Phillips, 1986).

Efficient DF-GLS and Ng-Perron unit root tests results are reported as follows:

Table 1

Unit Root Tests

\begin{tabular}{lllll}
\hline Variable & \multicolumn{2}{c}{ Levels } & \multicolumn{2}{c}{ First Difference } \\
\hline DF-GLS & Without Trend & With Trend & Without Trend & With Trend \\
\cline { 2 - 5 } UR & -1.5846 & -2.1676 & -1.1302 & $-3.59787^{\star *}$ \\
INF & -0.8390 & -1.4064 & -1.7470 & $-3.0144^{\star}$ \\
\hline Ng-Perron & & & & \\
UR & -1.51889 & -2.0605 & -2.1184 & $-4.4269^{\star *}$ \\
INF & $-4.4099^{\star *}$ & $-13.1577^{\star *}$ & $4.14099^{\star *}$ & $-13.1577^{\star * *}$ \\
\hline
\end{tabular}

Note: $* * *$ and $* * *$ denote stationary at $10 \%, 5 \%$ and $1 \%$ significance levels, respectively.

As observed in Table 1, unemployment rate is stationary in level depicting $\mathrm{I}(0)$ behavior, while inflation rate is nonstationary in level with $\mathrm{I}(1)$ behavior at 5 percent level of significance.

The ARDL estimates for co-integration corresponding to eqution (2) are reported as follows: 


$$
\begin{aligned}
& \Delta \mathrm{INF}_{t}= 0.9776-1.1874 \Delta U R_{\mathrm{t}-1}+0.1684 \Delta \mathrm{INF}_{\mathrm{t}-1}+ \\
&(2.3228) \quad(-12.5394)(2.4101) \\
&+ 0.1313 \mathrm{INF}_{\mathrm{t}-1}-0.3288 \mathrm{UR}_{\mathrm{t}-1} \ldots \ldots \ldots \ldots \ldots \ldots \ldots(2)^{\prime} \\
&(3.1179) \quad(-3.7047) \\
& \bar{R}^{2}=0.8752, \mathrm{~F}=149.2534, \mathrm{DW}=2.1732, \mathrm{AIC}=3.6807
\end{aligned}
$$

Table 2

ARDL Bounds Test

Null Hypothesis: No long-run relationships exist

\begin{tabular}{llll}
\hline \hline Test Statistic & Value & $k$ & \\
\hline \hline F-statistic & 4.27 & 1916 & 1 \\
\hline \hline Critical Value Bounds & & & \\
\hline \hline Significance & 10 Bound I1 & Bound & \\
\hline \hline $10 \%$ & 3.02 & 3.51 & \\
$5 \%$ & 3.62 & 4.16 & \\
$2.5 \%$ & 4.18 & 4.79 & \\
$1 \%$ & 4.94 & 5.58 & \\
\hline \hline
\end{tabular}

The coefficient of $\mathrm{UR}_{\mathrm{t}-1}$ and $\mathrm{INF}_{\mathrm{t}-1}$ in equation (2) are statistically significant and non-zeroes. The computed F istic for ARDL bounds testing is 4.27916 and above the upper bound critical

F-values at $5 \%$ and $10 \%$ levels of significance. Thus, the null hypothesis of no co-integration is rejected signify co-integrating relationship between inflation and unemployment rates over the sample period. To add further, low AIC-value at 3.6807 indicates good fit of the model with minimum loss of information. DWValue at 2.1732 indicates presence of very mild negative serial correlation in the time series data for the sample period.

Consequent upon the above, the vector error-correction model estimate relating to equation (3) are reported as follows: 


$$
\begin{aligned}
& \Delta \mathrm{INF}_{\mathrm{t}}=6.9136-0.3288 \Delta U R_{\mathrm{t}-1}-0.1684 \Delta \mathrm{UR}_{\mathrm{t}-2}+0.2158 \Delta \mathrm{INF}_{\mathrm{t}-1} \\
& \begin{array}{llll}
(4.0713) & (-3.9145) \quad(-3.6695)
\end{array} \\
& +0.1911 \Delta \mathrm{INF}_{\mathrm{t}-2}-0.1414 \mathrm{EC}_{\mathrm{t}-1} \\
& (-1.6257) \\
& \text { (-3.6244) } \\
& \bar{R}^{2}=0.2916, \mathrm{~F}=6.1865, \mathrm{AIC}=2.6916
\end{aligned}
$$

As expected, the error-correction term $\left(\mathrm{EC}_{\mathrm{t}-1}\right)$ has negative coefficient with statistical significance in terms of the associated pseudo t-value. This suggests convergence toward long- run equilibrium at a very slow pace of adjustment in terms of a tiny magnitude of the coefficient of the error-correction term. Moreover, the short-run feedback effects of lagged changes in unemployment rates on the current change in inflation rate are negative and statistically significant in terms of the associated t-values. However, past changes in unemployment rates can explain barely 29.16 percent of change in current inflation rate. The traditional Philips curve thus appears to be valid for the long run amid some short-run instability as shown by CUSUM-Square test (Pesaran and Pesaran, 1997) beyond 5\% confidence band (Appendix). However, for the overall sample period, it is relatively stable in terms of the CUSUM test. Again, low AIC-value at 2.6916 confirms good fit of the model with minimum loss of information.

\section{CONCLUSIONS AND POLICY IMPLICATIONS}

The empirics of the traditional Phillips curve clearly support the validity of the trade-off relationship between inflation and unemployment rates for the long run. However, the evidence for the short run is relatively weak and subdued in terms of the interactive feedback effects and associated t-values. Additionally, there is evidence of some short-run instability, as displayed by the CUSUM-Square test.

For policy implications, the Fed should focus on the long run to be able to exploit the traditional Phillips Curve relationship to navigate the economy on a desired trajectory through appropriate monetary and Federal funds rate adjustments. 


\section{$\overline{\text { REFERENCES }}$}

Akaike, H. (1969). Fitting autoregression for prediction. Annals of the Institute of Statistical Mathematics, 21: 243-247.

Atkeson A., \& Ohanian, L. E. (2001). Are Phillips curves useful for forecasting inflation? FRB Minneapolis Quarterly Review, 2-11.

Ball, L., \& S. Mazumder. (2011). Inflation Dynamics and the Great Recession. IMF Working Paper 11/121, Washington: International Monetary Fund.

Biancdhi, F., \& Civelli, A. (2015). Globalization and Inflation: Evidence from a Time-Varying VAR. Review of Economic Dynamics, Elsevier for the Society for Economic Dynamics, Vol.18(2), 406-433, April.

Blachard, O. (2016). The Phillips Curve: Back to the 60s? American Economic Review, 106(5):31-34.

Blachard, O., Cerutti, E., \& Summers, L. (2015). Inflation and Activity-Two Explorations and Their Monetary Policy Implication. NBER Working Paper 21726.

Constancio, V. (2014). Recent Challenges to Monetary Policy in the Euro Area. Speech by Vitor Constancio, Vice-President of the ECB, at the Athens Symposium on Banking Union, Monetary Policy and Economic Growth, Athens, June.

Del Boca, A. M., Fratianni, F.S., \& Trecroci, C. (2008). The Phillips curve and the Italian lira, 1861-1998. Working Paper, Department of Economics, University of Brescia.

Eliasson, A. (2001). Is the short-run Phillips curve nonlinear? Empirical evidence for Australia, Sweden and the United States.Sveriges Riksbank Working paper124, Stockholm School of Economics, Department of Economic Statistics.

Elliot, G., Rothenberg, T. J., \& Stock, J. H. (1996). "Efficient Test for an Autoregressive Unit Root". Econometrica, 64:813-836.

Engle, R. F., \& Granger, C.W.J. (1987). Co-integration and error-correction representation, estimation and testing. Econometrica, 55: 251-276.

Fitzgerald, T., \& J. P. Nicolini. (2013). Is There a Stable Relationship Between Unemployment and Future Inflation? Evidence from U.S. Cities, Working Paper. Federal Reserve Bank of Minneapolis.

Friedman, M. (1968). The role of monetary policy.American Economic Review, 68:1-17. Furuoka, F. (2007). Does the Phillips curve really exist? New empirical evidence from Malaysia.

Economics Bulletin, 5: 1-14. 
Gali, J., Gertler, M., \& Lopez-Salido, J.D. (2005). Robustness of the estimates of the hybrid New Keynesian Phillips curve. Journal of Monetary Economics, 52: 1107-1118.

Gilchrist, S., Schoenle, R., \& Zakrajsek, E. (2013). Inflation Dynamics During the Financial Crisis.Society for Economic Dynamics, 2013 Meeting Papers 826.

Graham, L., \& Snower, D. (2002). The return of the long-run Phillips curve. Working Paper, Department of Economics, Birkbeck College, University of London.

Granger, C.W.J. and Newbold, P. (1974). "Spurious Regressions in Econometrics." Journal of Econometrics, 2: 111-120.

Hansen, M., \& Pancs, R. (2001). The Latvian labour market transition: The Beveridge and Phillips curve as indicators of normalization.Riga: Euro Faculty.

Ihrig. J., S. Kamin, D. Linder, \& Marquez, J. (2010). Some simple tests of the globalization and inflation hypothesis. International Finance, Vol 13, no 3, 343375.

Islam, F. K., Hassan, M., \& Rahman, M. (2003). The empirics of US Phillips curve: A revisit. American Business Review, 20(1): 107-112.

Johansen, S. (1988). Statistical analysis of co-integration vectors.Journal of Economic Dynamics and Control, 12: 231-254.

Johansen, S. (1991). Estimation and hypothesis testing of co-integration vectors in Gaussian vector autoregressive models. Econometrica, 59 (6): 1551-1580.

Johansen, S., \& Juselius, K. (1990). Maximum likelihood estimation and inference on co- integration with application to the demand for money. Oxford Bulletin of Economics and Statistics, 52: 169-210.

Karanassou, M., Sala, H., \& Snower, D.J. (2008). The evolution of inflation and unemployment: Explaining the roaring nineties. Australian Economic Papers, 47(4): 334-354.

Karanassou, M., Sala, H., \& Snower, D.J. (2010). Phillips curves and unemployment dynamics: A critique and a holistic perspective. Journal of Economic Surveys, 24(1): 1-51.

Kiley, M. (2015). Low Inflation in the United States: A Summary of Recent Research. FEEDS Notes, November 23. Board of Governors of the Federal Reserve System.

Kwiatkowski, D., Phillips, P.C.B., Schmidt, P., and Shin, Y. (1992). "Testing the Null Hypothesis of Stationarity Against the Alternative of a Unit Root". Journal of Econometrics, 54:159-178.

Lipsey, R. G. (1960). The relation between unemployment and the rate of change of money wage rate in United Kingdom 1962-1951. Econometrica, 24: 1-12. 
Malinov, M. J., \& Sommers, P. M. (1997). A new line on the Phillips curve. Social Science Quarterly, 78(3): 740-746.

Ng, S. and Perron, P. (2001). "Lag Length Selection and the Construction of Unit Root Tests with Good Size and Power." Econmetrica, 64:813-836.

Niskanen, W.A. (2002). On the death of Phillips curve.Cato Journal, 22: 193-198. Ormerod, P., Rosewell, B., \& Phelps, P. (2013). Inflation/unemployment regimes and the instability of the Phillips curve.Applied Economics, 45(2): 1519-1531.

Paul, B.P. (2009). In search of the Phillips Curve for India. Journal of Asian Economics, 20: 479-488.

Pesaran, H., M., Shin, Y., \& Smith, R. J. (2001). Bounds testing approaches to the analysis of level relationships. Journal of Applied Econometrics, 16 (3): 289326.

Pesaran, M.H., \& Pesaran, B. (1997). 'Working with Microfit 4.0: Interactive Econometric Analysis.' Oxford University Press, U.K.

Pesaran, M.H., \& Shin, Y. (1999). 'An autoregressive distributed lag-Modeling Approach to Cointegration Analysis, In Econometrics and Economic Theory in the 20th Century: The Ragnar Frisch Centennial Symposium, S. Strom Ed. Cambridge University Press, U.K., pp. 371-413.

Phillips, A.W. (1958). The relationship between unemployment and the rate of change of money wage rates in the United Kingdom. Econometrica, 25: 258299.

Phillips, P.C.B. (1986). "Understanding Spurious Regressions in Econometrics." Journal of Econometrics, 33:311-340.

Reichel, R. (2004). On the death of the Phillips curve: Further evidence. Cato Journal, 24: 341-348.

Rudd, J., \& Whelan, K. (2005). New tests of the New Keynesian Phillips curve. Journal of Monetary Economics, 52: 1167-1181.

Russell, B., \& Banerjee, A. (2008). The long-run Phillips curve and non-stationary inflation. Journal of Macroeconomics, 30: 1792-1815.

Tang, C.F., \& Lean, H.H. (2007). The stability of Phillips curve in Malaysia. Discussion paper- 39, Monash University.

Turner, D., \& Segnezza, E. (1999). Testing for a common OECD Phillips curve. Economics Department Working paper no. 219, OECD.

Turner, P. (1997). The Phillips curve, parameter instability and the Lucas critique. Applied Economics, 29(1): 7-10. 


\section{BRIEF BIOGRAPHICAL SKETCH OF AUTHORS}

Muhammad Mustafa is a Professor of Economics at the South Carolina State University, Carolina, USA. He is an Avid Researcher and published very extensively in refereed US and foreign academic journals. He has a diverse teaching portfolio and long teaching experience. He is a distinguished educator.

Matiur Rahman is a JP Morgan Chase Endowed Professor at the McNeese State University, Louisiana, USA. He earned his $\mathrm{PhD}$ in Economics from the South Methodist University, Texas USA. He is a very prolific Researcher. He has published numerous impactful papers on diverse topics in economics and finance of current interests.

\section{$\overline{\text { APPENDIX }}$}

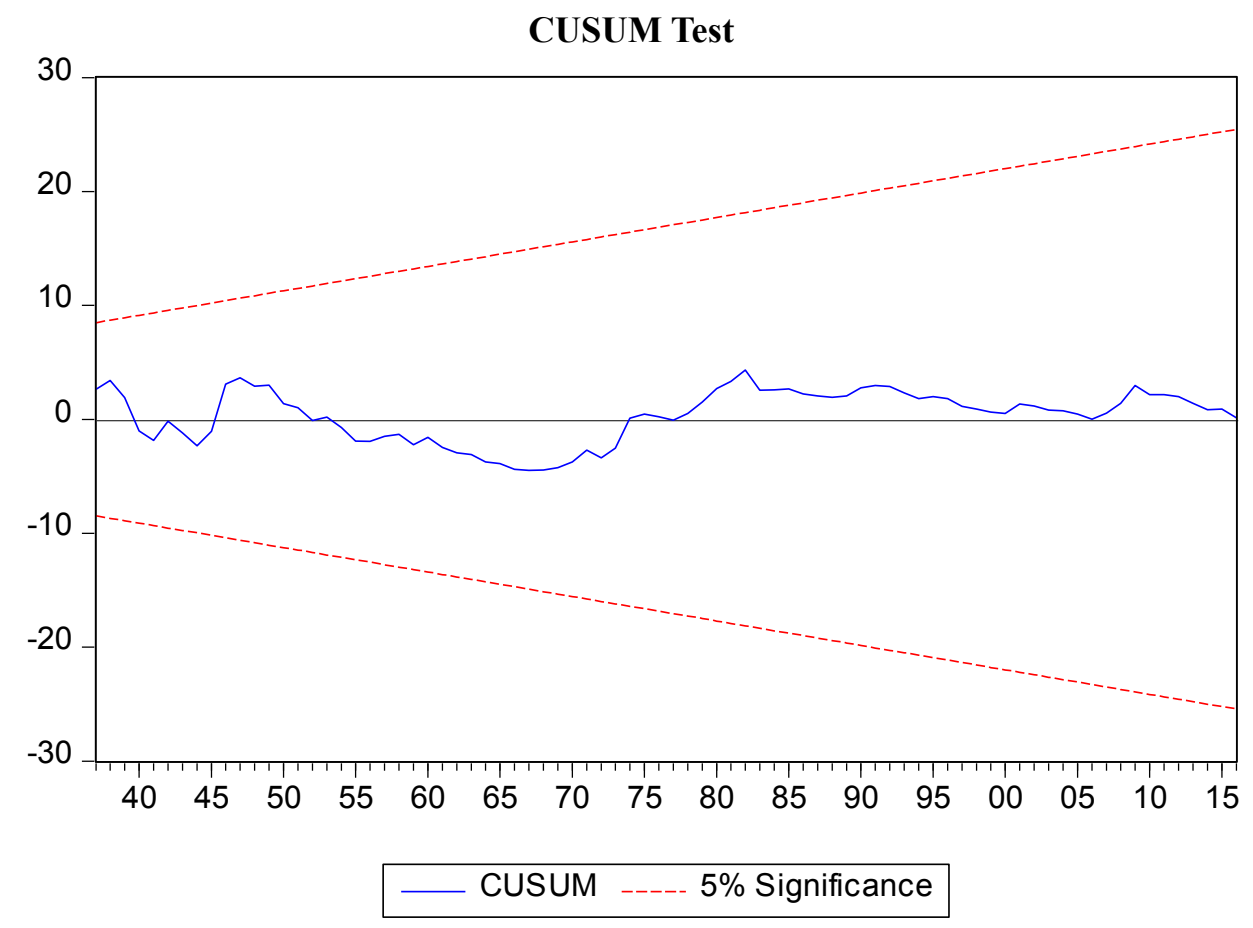


CUSUM-Squares Test

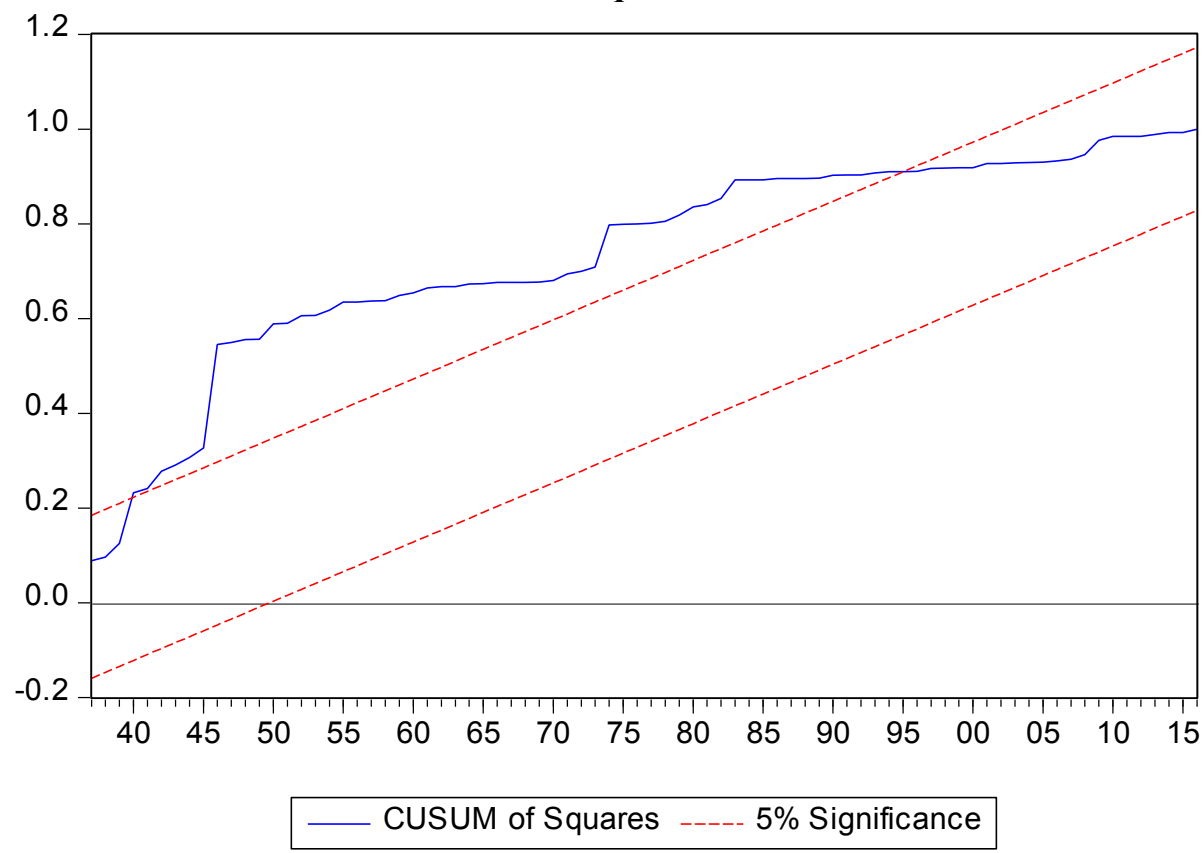

